\title{
The impact of ambroxol on the anti-inflammatory effect of azithromycin in lung tissue
}

\author{
Ayse Er ${ }^{1}$, Burak Dikㅁ, Devran Coskun ${ }^{2}$, Hatice Eser Faki', and Emre Bahcivan ${ }^{3}$ \\ ${ }^{1}$ Department of Pharmacology and Toxicology, Faculty of Veterinary Medicine, Selcuk University, Konya, Turkey \\ ${ }^{2}$ Department of Pharmacology and Toxicology, Faculty of Veterinary Medicine, Siirt University, Siirt, Turkey \\ ${ }^{3}$ Department of Pharmacology and Toxicology, Faculty of Veterinary Medicine, Kafkas University, Kars, Turkey
}

ER, A., B. DIK, D. COSKUN, H. ESER FAKI, E. BAHCIVAN: The impact of ambroxol on the antiinflammatory effect of azithromycin in lung tissue. Vet. arhiv 91, 665-671, 2021.

\section{ABSTRACT}

The aim of this study was to compare the effects of two different doses of ambroxol (AMB) co-administered with azithromycin (AZIT) on the concentrations of bronchoalveolar lavage fluid (BALF) cytokines and serum biochemical parameters in an lipopolysaccharide (LPS)-induced acute lung injury mouse model. A total of 78 male Swiss albino mice were used for this investigation. After six mice had been separated as the control group ( 0 hours), the remaining animals were divided into the following three equal groups: LPS, LPS+AZIT+AMB30 and LPS+AZIT+AMB70. LPS, AZIT and AMB were administered intraperitoneally. BALF and serum samples were collected before (0 hour) and after applications at 4, 8,16 and 24 hours under general anaesthesia, and then all mice were euthanised by cervical dislocation. Concentrations of tumor necrosis factor (TNF) $\alpha$, interleukin (IL)-6 and IL-10 in BALF and aspartate aminotransferase (AST), alkaline phosphatase (ALP), urea and creatinine concentrations in serum were determined. Elevated TNF $\alpha$ and IL- 6 concentrations in the LPS group were prevented at 8 and 16 hours in LPS+AZIT+AMB30 group. In addition, both treatment groups inhibited elevated IL- 6 concentrations in the LPS group at 16 hours. LPS+AZIT+AMB30 and LPS+AZIT+AMB70 increased IL-10 concentrations at 16 and 4 hours, respectively. LPS caused significant elevations in urea concentrations at all sampling times and statistical fluctuations in other parameters at different sampling times. The increased ALP concentration in LPS group decreased in the treatment groups at 8 hours. In conclusion, the combination of low-dose AMB and AZIT may achieve beneficial effects in pulmonary infections by influencing the cytokine network.

Key words: acute lung injury; ambroxol; azithromycin; BALF; cytokine

\section{Introduction}

Acute respiratory distress syndrome and acute lung injury (ALI) can arise from various diseases and conditions such as sepsis, the aspiration of gastric contents, pneumonia and acute pancreatitis. Affected patients show neutrophil-derived inflammation, surfactant dysfunction and lung oedema (MOKRA and KOSUTOVA, 2015). Acute lung injury remains a major cause of high rates of mortality/morbidity and health care costs in critically ill patient (RUBENFELD and HERRIDGE, 2007). However, deficiencies in the prevention and treatment of ALI persist (WANG et al., 2014a).

*Corresponding author:

Ayse Er, Department of Pharmacology and Toxicology, Veterinary Faculty, Selcuk University, 42031, Konya, Turkey, E-mail: aer@selcuk.edu.tr 
Biomarkers in the bronchoalveolar lavage fluid (BALF) of patients can provide information regarding the severity and other characteristics of ALI. Neutrophils and alveolar macrophages produce cytokines that play a crucial role in inflammatory response. Meanwhile, a complex network of cytokines initiates, amplifies and perpetuates the inflammatory response in ALI (WARE and MATTHAY, 2000; MOKRA and KOSUTOVA, 2015).

An LPS-induced model of ALI can present a similar inflammatory response with an increase in intrapulmonary cytokines, while the alveolarcapillary permeability changes remain mild (MOKRA and KOSUTOVA, 2015). Therefore, LPS has been used to create a serious lung injury model in studies (ZHANG et al., 2015; SONG et al., 2017). LPS, the immunogenic component of the gram (-) bacterial cell wall (VARATHARAJ and GALEA, 2017), first induces tumor necrosis factor (TNF) (VAN DER POLL, 2001). Subsequently, other pro-inflammatory cytokines, such as interleukin (IL)-6, are released (VAN DEVENTER et al., 1990). Significant TNF $\alpha$ and IL-6 concentrations have been reported during the inflammatory process of the respiratory system (LARKI-HARCHEGANI et al., 2013). IL-10, an anti-inflammatory cytokine, reduces the synthesis of pro-inflammatory cytokines. When the balance between pro-inflammatory and anti-inflammatory cytokines is disrupted in favour of the former, their harmful effects prevail (BOSCOLO et al., 2008).

Macrolide antibiotics have anti-inflammatory efficacy as well as antibacterial activity due to their influence in several processes of inflammation, including the production of various cytokines and the migration of neutrophils (SCAGLIONE and ROSSONI, 1998; WALES and WOODHEAD, 1999; ZALEWSKA-KASZUBSKA and GÓRSKA, 2001). It has been reported that azithromycin (AZIT), a macrolide antibiotic, decreases TNF $\alpha$ concentrations and increases IL-10 concentrations (ER, 2013). Ambroxol hydrochloride (AMB) is used as a mucolytic agent in respiratory system diseases. In addition, it has shown anti-inflammatory activity by reducing pro-inflammatory cytokines in both in vitro and in vivo studies (BEEH et al., 2008).
In cases of ALI, neutrophil migration, edema and increased TNF $\alpha$ and IL- 6 concentrations in the lung tissue (WANG et al., 2006; ER and YAZAR, 2012; CAI et al., 2016) were reduced by AMB (SU et al., 2004; DONG et al., 2012; GE et al., 2016). It has been also reported that AMB has a protective effect against lung fibrosis caused by paraquat (ZHI et al., 2011), and an enhancing effect (TAKEDA et al., 2016) on the low IL-10 concentrations observed in relation to lung inflammation (GOODMAN et al., 2003).

Organ damage can be defined by some biomarkers in the blood. The measurement of these parameters in serum or plasma provides information about the safety of the drugs being taken, or the course of the disease. Aspartate aminotransferase (AST) and alkaline phosphatase (ALP) concentrations are used as liver damage biomarkers, while urea and creatinine concentrations are accepted as kidney damage biomarkers (COSKUN et al., 2019).

In this study, the positive effects of AZIT (ER, 2013) and AMB (BEEH et al., 2008) on cytokines were taken into consideration; it was hypothesised that they may modulate the cytokine networks and prevent organ damage in an LPS-induced ALI model when given concurrently.

The aim of this study was to compare the effects of two different doses of AMB administered with AZIT on the concentrations of BALF cytokines (TNF $\alpha$, IL-6, IL-10) and serum biochemical (AST, ALP, urea, creatinine) parameters in an LPSinduced ALI mouse model.

\section{Materials and methods}

Chemicals. Lipopolysaccharide (LPS, Escherichia coli O111:B4, Sigma-Aldrich St. Louis, MO, USA), azithromycin [AZIT, Azithromycin dihydrate $\geq 98 \%$ (HPLC) (Sigma Aldrich, PZ0007)], ambroxol (AMB, ambroxol hydrochloride, Sigma Aldrich, A9797) and Pental Na (IE Ulagay, Turkey) were purchased.

Animals and experimental design. A total of 78 male Swiss albino mice (8 weeks, 30-35 g) were used in this study, which was approved by the Ethics Committee of the Experimental Medical Practice and Research Center of Animal Experiments at Selcuk University (2016-46). 
After 6 mice had been separated out as the control group, the remaining animals were divided into 3 equal groups, as follows: LPS [10 $\mathrm{mg} / \mathrm{kg}$, intraperitoneally (IP)], LPS (10 mg/kg, IP) + AZIT $(50 \mathrm{mg} / \mathrm{kg}, \mathrm{IP})+\mathrm{AMB} 30(30 \mathrm{mg} / \mathrm{kg}, \mathrm{IP})$ and LPS $(10 \mathrm{mg} / \mathrm{kg}, \mathrm{IP})+$ AZIT $(50 \mathrm{mg} / \mathrm{kg}, \mathrm{IP})+$ AMB70 $(70 \mathrm{mg} / \mathrm{kg}$, IP). ALI was induced by intraperitoneal administration of $10 \mathrm{mg} / \mathrm{kg}$ Escherichia coli B111:O4 LPS into the mice. All applications were performed simultaneously. BALF and blood samples were taken from 6 mice at each sampling time under general anaesthesia at 4, 8, 16 and 24 $\mathrm{h}$ post-administration. All mice were euthanised by cervical dislocation after treatments. The BALF and blood samples were centrifuged (1200 rpm, 4 ${ }^{\circ} \mathrm{C}, 10 \mathrm{~min}$ ) and stored at $-80{ }^{\circ} \mathrm{C}$ until analysis.

Analysis of inflammatory mediators and biochemical parameters. TNF $\alpha$ (Invitrogen, Carlsbad, CA, USA), IL-6 (eBioscience, San Diego, CA, USA) and IL-10 (eBioscience, USA) concentrations of BALF were determined by ELISA reader (MWGt Lambda Scan 200, USA) according to the manufacturer's instructions. Concentrations of serum AST, ALP, urea and creatinine were determined with an autoanalyser (Architect c8000; Abbott Laboratories, Chicago, IL, USA).

Statistical analysis. Concentrations of cytokines and serum biochemical parameters were evaluated by analysis of variance and Duncan's tests (SPSS 22.0). The results are presented as mean \pm standard error. The value $\mathrm{P}<0.05$ was taken to indicate statistical significance.

\section{Results}

Concentrations of TNF $\alpha$, IL- 6 and IL-10 are presented in Figs 1, 2 and 3, respectively. LPS caused statistically significant increases in the TNF $\alpha$ and IL- 6 concentrations in LPS group $(\mathrm{P}<0.05)$. LPS + AZIT + AMB70 did not inhibit the increases in TNF $\alpha$ concentrations, whereas LPS + AZIT + AMB30 prevented increases at 8 and 16 hours in the LPS group $(\mathrm{P}<0.05)$. In addition, both treatment groups inhibited the elevated IL-6 concentration in the LPS group at 16 hours $(\mathrm{P}<0.05)$. LPS decreased IL-10 concentration in the LPS group $(\mathrm{P}>0.05)$. LPS $+\mathrm{AZIT}+\mathrm{AMB} 30$ and LPS + AZIT + AMB70 treatments increased the IL-10 concentrations at 16 and 4 hours $(\mathrm{P}<0.05)$, respectively.

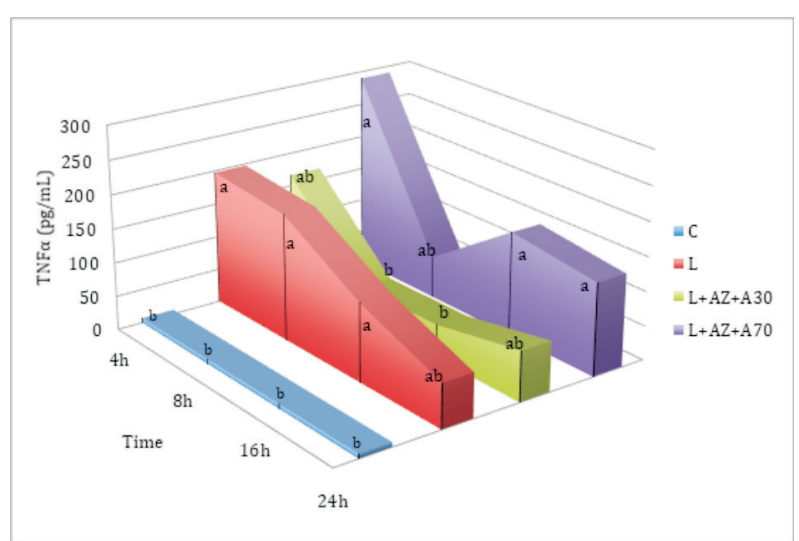

Fig. 1. Effects of azithromycin $(50 \mathrm{mg} / \mathrm{kg}$, IP) + ambroxol (30 mg/kg, IP) and azithromycin (50 $\mathrm{mg} / \mathrm{kg}$, IP) + ambroxol $(70 \mathrm{mg} / \mathrm{kg}$, IP) on the TNF $\alpha$ concentration in lipopolysaccharide-induced acute lung injury mouse model. TNF: tumour necrosis factor; $\mathrm{C}$ : control; L: lipopolysaccharide; AZ: azithromycin; A: ambroxol

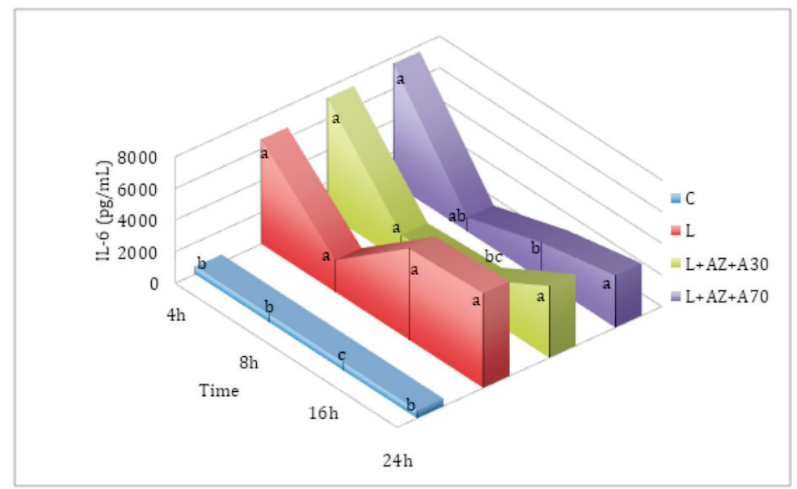

Fig. 2. Effects of azithromycin $(50 \mathrm{mg} / \mathrm{kg}$, IP) + ambroxol (30 mg/kg, IP) and azithromycin (50 $\mathrm{mg} / \mathrm{kg}, \mathrm{IP})+\operatorname{ambroxol}(70 \mathrm{mg} / \mathrm{kg}$, IP) on the IL-6 concentration in lipopolysaccharide-induced acute lung injury mouse model. IL: interleukin; C: control; L: lipopolysaccharide; AZ: azithromycin; A: ambroxol.

Biochemical values are presented in Table 1. Compared with the control group, LPS alone triggered a persistent increase in the urea concentration and statistical fluctuations in the other parameters during the experimental period $(\mathrm{P}<0.05)$. Also, the LPS-induced ALP concentration increase was prevented by both treatment groups at $8 \mathrm{~h}(\mathrm{P}<0.05)$. In other parameters, although both treatment groups generally showed lower increases caused in the LPS group at different sampling times, no statistical difference was found. 
A. Er et al.: Ambroxol alters the anti-inflammatory effect of azithromycin

Table 1. Effects of azithromycin (50 mg/kg, IP) + ambroxol (30 mg/kg, IP) and azithromycin (50 mg/kg, IP) + ambroxol $(70 \mathrm{mg} / \mathrm{kg}$, IP) on serum biochemical parameters in lipopolysaccharide-induced acute lung injury mouse model (mean $\pm \mathrm{SE})$

\begin{tabular}{|c|c|c|c|c|c|}
\hline & Group & $4 \mathrm{~h}$ & $8 \mathrm{~h}$ & $16 \mathrm{~h}$ & $24 \mathrm{~h}$ \\
\hline \multirow{4}{*}{ 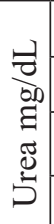 } & Control & $46.80 \pm 3.03^{\mathrm{b}}$ & $46.80 \pm 3.03^{\mathrm{b}}$ & $46.80 \pm 3.03^{\mathrm{b}}$ & $46.80 \pm 3.03^{\mathrm{b}}$ \\
\hline & LPS & $94.40 \pm 2.71^{\mathrm{a}}$ & $124.80 \pm 12.66^{\mathrm{a}}$ & $234.80 \pm 14.00^{\mathrm{a}}$ & $265.20 \pm 32.92^{\mathrm{a}}$ \\
\hline & LPS+AZIT+AMB30 & $96.60 \pm 9.11^{\mathrm{a}}$ & $119.60 \pm 10.52^{\mathrm{a}}$ & $203.20 \pm 11.90^{\mathrm{a}}$ & $248.60 \pm 65.31^{\mathrm{a}}$ \\
\hline & LPS+AZIT+AMB70 & $103.2 \pm 5.18^{\mathrm{a}}$ & $98.80 \pm 13.92^{\mathrm{a}}$ & $192.80 \pm 42.08^{\mathrm{a}}$ & $343.75 \pm 23.07^{\mathrm{a}}$ \\
\hline \multirow[b]{4}{*}{$\vec{u}$} & Control & $0.24 \pm 0.02^{\mathrm{a}}$ & $0.24 \pm 0.02^{\mathrm{a}}$ & $0.24 \pm 0.02^{b}$ & $0.24 \pm 0.02^{b}$ \\
\hline & LPS & $0.32 \pm 0.02^{\mathrm{a}}$ & $0.30 \pm 0.02^{\mathrm{a}}$ & $0.41 \pm 0.06^{\mathrm{a}}$ & $0.38 \pm 0.04^{\mathrm{ab}}$ \\
\hline & LPS+AZIT+AMB30 & $0.30 \pm 0.04^{\mathrm{a}}$ & $0.34 \pm 0.05^{\mathrm{a}}$ & $0.39 \pm 0.02^{\mathrm{a}}$ & $0.41 \pm 0.06^{\mathrm{ab}}$ \\
\hline & LPS+AZIT+AMB70 & $0.27 \pm 0.02^{\mathrm{a}}$ & $0.24 \pm 0.02^{\mathrm{a}}$ & $0.40 \pm 0.02^{\mathrm{a}}$ & $0.55 \pm 0.08^{\mathrm{a}}$ \\
\hline \multirow{4}{*}{\begin{tabular}{l}
$\overrightarrow{5}$ \\
$\vdots$ \\
5 \\
\multirow{2}{*}{}
\end{tabular}} & Control & $82.40 \pm 20.51^{\mathrm{b}}$ & $82.40 \pm 20.51^{\mathrm{a}}$ & $82.40 \pm 20.51^{\mathrm{a}}$ & $82.40 \pm 20.51^{b}$ \\
\hline & LPS & $252.40 \pm 89.22^{\mathrm{a}}$ & $181.20 \pm 36.77^{\mathrm{a}}$ & $356.40 \pm 126.55^{\mathrm{a}}$ & $398.40 \pm 121.66^{\mathrm{a}}$ \\
\hline & LPS+AZIT+AMB30 & $177.80 \pm 34.53^{\mathrm{ab}}$ & $139.75 \pm 54.64^{\mathrm{a}}$ & $274.80 \pm 58.90^{\mathrm{a}}$ & $322.40 \pm 67.08^{\mathrm{a}}$ \\
\hline & LPS+AZIT+AMB70 & $153.80 \pm 34.97^{\mathrm{ab}}$ & $168.40 \pm 44.14^{\mathrm{a}}$ & $249.20 \pm 94.85^{\mathrm{a}}$ & $347.60 \pm 52.98^{\mathrm{a}}$ \\
\hline \multirow{4}{*}{$\begin{array}{l}2 \\
5 \\
2 \\
0 \\
2\end{array}$} & Control & $36.20 \pm 8.49^{a}$ & $36.20 \pm 8.49^{b}$ & $36.20 \pm 8.49^{\mathrm{a}}$ & $36.20 \pm 8.49^{\mathrm{a}}$ \\
\hline & LPS & $52.40 \pm 6.59^{\mathrm{a}}$ & $80.02 \pm 10.37^{\mathrm{a}}$ & $31.60 \pm 6.56^{\mathrm{a}}$ & $32.60 \pm 6.34^{\mathrm{a}}$ \\
\hline & LPS+AZIT+AMB30 & $44.00 \pm 8.87^{\mathrm{a}}$ & $50.40 \pm 12.07^{\mathrm{b}}$ & $28.00 \pm 4.65^{\mathrm{a}}$ & $41.60 \pm 13.86^{\mathrm{a}}$ \\
\hline & LPS+AZIT+AMB70 & $47.60 \pm 4.22^{\mathrm{a}}$ & $37.20 \pm 3.73^{b}$ & $22.40 \pm 6.66^{\mathrm{a}}$ & $55.20 \pm 5.05^{\mathrm{a}}$ \\
\hline
\end{tabular}

${ }^{\mathrm{a}, \mathrm{b}}$ : Different letters in the same column are statistically significant $(\mathrm{P}<0.05)$. Cre; creatinine, AST; aspartate aminotransferase, ALP; alkaline phosphatase

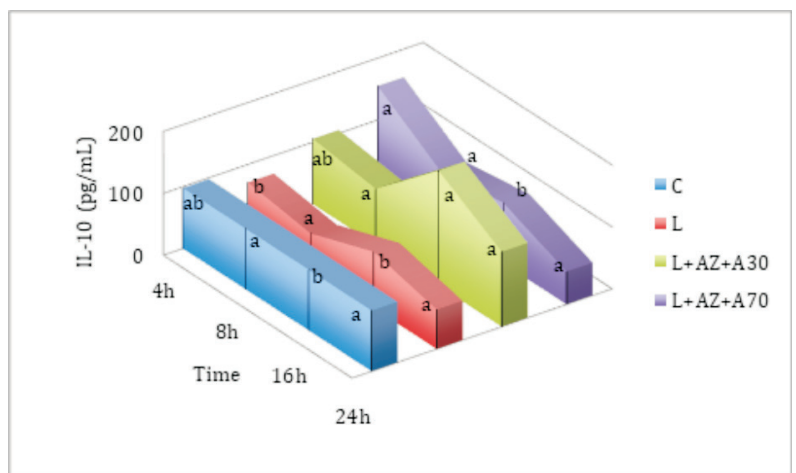

Fig. 3. Effects of azithromycin $(50 \mathrm{mg} / \mathrm{kg}$, IP)+ambroxol (30 mg/kg, IP) and azithromycin (50 $\mathrm{mg} / \mathrm{kg}$, IP)+ambroxol (70 mg/kg, IP) on the IL-10 concentration in lipopolysaccharide-induced acute lung injury mouse model. IL: interleukin; C: control; L: lipopolysaccharide; AZ: azithromycin; A: ambroxol.

\section{Discussion}

Sepsis is one of the most common causes of ALI and, currently, there are deficiencies in its prevention and treatment (WANG et al., 2014a). The intraperitoneal administration of LPS is used to create a serious lung injury model (ZHANG et al., 2015; SONG et al., 2017). The endothelial barriers are disrupted by inflammation, resulting in lung injury (BHATIA and MOOCHHALA, 2004). ALI is the result of various elements such as cytokines playing a role in the inflammatory response (ILIODROMITI et al., 2013). TNF and IL-6 are pro- inflammatory cytokines, while IL-10 is an antiinflammatory cytokine (QUINTANS et al., 2019). Thus, the prevention of lung inflammation could be an important aspect in ALI treatment (ZHANG et al., 2015).

In this study, LPS increased the TNF $\alpha$ (Fig. 1) and IL-6 (Fig. 2) concentrations $(\mathrm{P}<0.05)$ and decreased the IL-10 (Fig. 3) concentration ( $\mathrm{P}>0.05)$. 
Treatment with $30 \mathrm{mg} / \mathrm{kg}$ of AMB + AZIT decreased the TNF $\alpha$ concentration relative to in the LPS group at 8 and 16 hours $(\mathrm{P}<0.05)$, while no such effect of treatment with $70 \mathrm{mg} / \mathrm{kg}$ of AMB+AZIT was observed. In addition, both treatment groups inhibited elevated IL-6 concentration as compared with the LPS group at 16 hours. LPS has been used to create a lung injury model in previous studies (ZHANG et al., 2015; SONG et al., 2017). In addition, LPS administration resulted in increased concentrations of TNF and IL-6 (WU et al., 2015; ZHANG et al., 2015; TANG et al., 2016) and decreased concentration of IL-10 in BALF (GE et al., 2010). It has been reported that tylosin, tilmicosin and AZIT caused decreases in the concentrations of TNF and IL-6 in BALF and the lungs (ER and YAZAR, 2012; TANG et al., 2017). In addition, pyrrolidine dithiocarbamate and abamectin caused decreases in the concentrations of TNF and IL-6 in mouse BALF (ZHANG et al., 2011; WANG et al., 2014b). In our study, treatment with $30 \mathrm{mg} / \mathrm{kg}$ of AMB+AZIT increased the IL-10 concentration compared with the LPS group at 16 hours, while treatment with $70 \mathrm{mg} / \mathrm{kg}$ of AMB+AZIT increased at 4 hours $(\mathrm{P}<0.05)$. Resolvin D1 and asiaticoside increased the IL-10 concentration in BALF as compared with the LPS group (ZHANG et al., 2008; WANG et al., 2014c). In this study, the alterations in cytokine concentrations in the LPS and treatment groups were found to be similar to those of other studies with both an LPS-model group and groups treated with anti-inflammatory agents. Although AMB is known to increase the level of antibiotics in the lung (DERETIC and TIMMINS, 2019), the present study results may indicate that a low-dose AMB combination with AZIT has beneficial effects on ALI by increasing the IL-10 concentration and decreasing TNF or IL-6 concentrations.

Lipopolysaccharide increased the urea concentration and caused statistical fluctuations in the form of an increase in the creatinine, AST and ALP concentrations at different sampling time points $(\mathrm{P}<0.05$, Table 1$)$. However, the treatment prevented the increase in ALP concentration in the LPS group at 8 hours. Treatment with AZIT + AMB could not prevent the increase in urea concentration, while other parameters remained generally similar to those of the control group. In experimental studies, following LPS administration increased serum biochemical parameters were reported (ER and YAZAR, 2010; ER and DIK, 2014). As some biomarkers measured in the blood provide information about organ damage, LPS may be observed to cause partial kidney dysfunction.

\section{Conclusion}

The use of low-dose AMB together with AZIT may have beneficial effects in the management of pulmonary infections. Therefore, the use of AMB in addition to AZIT treatment should be examined further in studies on complex or severe lung diseases. In addition, this study may support geneexpression studies on this subject in lung tissue.

\section{Conflicts of interest statement}

The authors declare that there are no conflicts of interest.

\section{Acknowledgements}

We thank Dr Enver Yazar for his scientific assistance. The study abstract was presented as a poster that the International Conference on Veterinary, Agriculture and Life Sciences (ICVALS) on October 27-29, 2017, in Alanya, Turkey.

\section{References}

BEEH, K. M., J. BEIER, A. ESPERESTER, L. D. PAUL (2008): Antiinflammatory properties of ambroxol. Eur. J. Med. Res. 13, 557-562.

BHATIA, M., S. MOOCHHALA (2004): Role of inflammatory mediators in the pathophysiology of acute respiratory distress syndrome. J. Pathol. 202, 145-156.

DOI: $10.1002 /$ path.1491

BOSCOLO, P., P. YOUINOU, T. C. THEOHARIDES, G. CERULLI, P. CONTI (2008): Environmental and occupational stress and autoimmunity. Autoimmun. Rev. 7, 340-343.

DOI: 10.1016/j.autrev.2007.12.003

CAI Z, J. LIU, H. BIAN, J. CAI, G. ZHU (2016): Suppression of P2X7/NF- $\mathrm{BB}$ pathways by Schisandrin B contributes to attenuation of lipopolysaccharide-induced inflammatory responses in acute lung injury. Arch. Pharm. Res. 39, 499507.

DOI: $10.1007 / \mathrm{s} 12272-016-0713-0$

COSKUN, D., B. DIK, Y. KORKMAZ, R. CANBAR, A. ER, E. YAZAR (2019): Investigation of cardiotoxic effects of marbofloxacin. Eurasian J. Vet. Sci. 35, 56-61.

DOI: 10.15312/EurasianJVetSci.2019.223 
DERETIC, V., G. TIMMINS (2019): Enhancement of lung levels of antibiotics by ambroxol and bromhexine. Enhancement of lung levels of antibiotics by ambroxol and bromhexine. Expert Opin. Drug Metab. Toxicol. 15, 213-218 DOI: $10.1080 / 17425255.2019 .1578748$

DONG, C., G. WANG, B. LI, K. XIAO, Z. MA, H. HUANG, X. WANG, C. BAI (2012): Anti-asthmatic agents alleviate pulmonary edema by upregulating AQP1 and AQP5 expression in the lungs of mice with OVA-induced asthma. Respir. Physiol. Neurobiol. 181, 21-28.

DOI: 10.1016/j.resp.2011.12.008

ER, A. (2013): Azithromycin prevents pregnancy loss: Reducing the level of tumor necrosis factor-alpha and raising the level of interleukin-10 in rats. Mediators of Inflamm. 928137.

DOI: $10.1155 / 2013 / 928137$

ER, A., B. DIK (2014): The effects of florfenicol on the values of serum tumor necrosis factor- $\alpha$ and other biochemical markers in lipopolysaccharide-induced endotoxemia in brown trout. Mediators Inflamm. 464373.

DOI: $10.1155 / 2014 / 464373$

ER, A., E. YAZAR (2010): Effects of macrolide antibiotics on blood inflammatory mediators and organ damage markers in lipopolysaccharide-induced pulmonary damage rats. Eurasian J. Vet. Sci. 26, 7-13.

ER, A., E. YAZAR (2012): Effects of tylosin, tilmicosin and tulathromycin on inflammatory mediators in bronchoalveolar lavage fluid of lipopolysaccharideinduced lung injury. Acta Vet. Hung. 60, 465-476.

DOI: $10.1556 /$ avet.2012.041

GE, L. T., Y. N. LIU, X. X. LIN, H. J. SHEN, Y. L JIA, X. W. DONG, Y. SUN, Q. XIE (2016): Inhalation of ambroxol inhibits cigarette smoke-induced acute lung injury in a mouse model by inhibiting the Erk pathway. Int. Immunopharmacol. 33, 90-98.

DOI: 10.1016/j.intimp.2016.02.004

GE, Z. J., G. J. JIANG, Y. P. ZHAO, G. X. WANG, Y. F. TAN (2010): Systemic perfluorohexane attenuates lung injury induced by lipopolysaccharide in rats: the role of heme oxygenase-1. Pharmacol. Rep. 62, 170-177.

DOI: 10.1016/S1734-1140(10)70254-1

GOODMAN, R. B., J. PUGIN, J. S. LEE, M. A. MATTHAY (2003): Cytokine-mediated inflammation in acute lung injury. Cytokine Growth Factor Rev. 14, 523-535.

DOI: 10.1016/S1359-6101(03)00059-5

ILIODROMITI, Z., D. ZYGOURIS, S. SIFAKIS, K. I. PAPPA, P. TSIKOURAS, N. SALAKOS, A. DANIILIDIS, C. SIRISTATIDIS, N. VRACHNIS (2013): Acute lung injury in preterm fetuses and neonates: mechanisms and molecular pathways. J. Matern. Fetal Neonatal Med. 26, 1696-1704.

DOI: $10.3109 / 14767058.2013 .798284$
LARKI-HARCHEGANI, A, A. A., HEMMATI, A. ARZI, M. GHAFURIAN-BOROOJERDNIA, S. SHABIB, M. R. ZADKARAMI, S. ESMAEILZADEH (2013): Evaluation of the effects of caffeic acid phenethyl ester (CAPE) on prostaglandin E2 and two key cytokines involve in bleomycin-induced pulmonary fibrosis. Iran J. Basic. Med. Sci. 16, 850-857.

MOKRA, D., P. KOSUTOVA (2015): Biomarkers in acute lung injury. Respir. Physiol. Neurobiol. 209, 52-58.

DOI: $10.1016 /$ j.resp.2014.10.006

QUINTANS, J. S. S., S. SHANMUGAM, L. HEIMFARTH, A. A. S. ARAÚJO, J. R. G. D. S ALMEIDA, L. PICOT, L. J. QUINTANS-JÚNIOR (2019): Monoterpenes modulating cytokines-A review. Food Chem. Toxicol. 123, 233-257. DOI: $10.1016 /$ j.fct.2018.10.058

RUBENFELD, G. D., M. S. Herridge (2007): Epidemiology and outcomes of acute lung injury. Chest 131, 554-562. DOI: $10.1378 /$ chest.06-1976

SCAGLIONE, F., G. ROSSONI (1998): Comparative antiinflammatory effects of roxithromycin, azithromycin and clarithromycin. J. Antimicrob. Chemother. 41, 47-50.

DOI: $10.1093 /$ jac/41.suppl 2.47

SONG, H. W., C. YANG, W. LIU, X. W. LIU, Z. LIU, F. GAO (2017): Interleukin-17A plays the same role on mice acute lung injury respectively induced by lipopolysaccharide and paraquat. inflammation. 40, 1509-1519.

DOI: 10.1007/s10753-017-0592-7

SU, X., L. WANG, Y. SONG, C. BAI (2004): Inhibition of inflammatory responses by ambroxol, a mucolytic agent, in a murine model of acute lung injury induced by lipopolysaccharide. Intensive Care Med. 30, 133-140. DOI: 10.1007/s00134-003-2001-y

TAKEDA, K., N. MIYAHARA, S. MATSUBARA, C. TAUBE, K. KITAMURA, A. HIRANO, M. TANIMOTO, E. W. GELFAND (2016): Immunomodulatory effects of ambroxol on airway hyperresponsiveness and inflammation. Immune Netw. 16, 165-175.

DOI: $10.4110 /$ in.2016.16.3.165

TANG, F., R. LI, J. XUE, J. LAN, H. XU, Y. LIU Y, L. ZHOU, Y. LU (2017): Azithromycin attenuates acute radiationinduced lung injury in mice. Oncol. Lett. 14, 5211-5220. DOI: $10.3892 / \mathrm{ol} .2017 .6813$

TANG, M., L. CHEN, B. LI, Y. WANG, S. LI, A. WEN, S. YAO, Y. SHANG (2016): BML-111 attenuates acute lung injury in endotoxemic mice. J. Surg. Res. 200, 619-630. DOI: $10.1016 /$ j.jss.2015.09.005

VAN DER POLL, T (2001): Immunotherapy of sepsis. Lancet Infect. Dis. 1, 165-174. DOI: 10.1016/S1473-3099(01)00093-7

VAN DEVENTER, S. J., H. R. BULLER, J. W. TEN CATE, L. A. AARDEN, C. E. HACK, A. STURK (1990): Experimental endotoxemia in humans: Analysis of cytokine release and coagulation, fibrinolytic, and complement pathways. Blood. 76, 2520-2526.

DOI: 10.1182/blood.V76.12.2520.2520 
VARATHARAJ, A., I. GALEA (2017): The blood-brain barrier in systemic inflammation. Brain Behav. Immun. 60, 1-12. DOI: $10.1016 /$ j.bbi.2016.03.010

WALES, D., M. WHOODHEAD (1999): The anti-inflammatory effects of macrolides. Thorax 54, 58-62. DOI: $10.1136 /$ thx.54.2008.S58

WANG, X., H. LI, Z. XIA (2014a): Advances in the study of the relationship between autophagy and sepsis-induced lung injury. Zhonghua Shao Shang Za Zhi. 30, 325-328.

WANG, H., L. XU, J. ZHAO, D. WANG, R. GUO, J. WANG, W. GONG, T. LIU, Y. ZHANG, L. DONG (2014b): Regulatory mechanism of pyrrolidine dithiocarbamate is mediated by nuclear factor- $\mathrm{KB}$ and inhibits neutrophil accumulation in ARDS mice. Exp. Ther. Med. 8, 614-622. DOI: $10.3892 /$ etm.2014.1738

WANG, L., R. YUAN, C. YAO, Q. WU, M. CHRISTELLE, W. XIE W, X. ZHANG, W. SUN, H. WANG, S. YAO (2014c): Effects of resolvin D1 on inflammatory responses and oxidative stress of lipopolysaccharide-induced acute lung injury in mice. Chin. Med. J. 127, 803-809.

WANG, X. Q., K. BDEIR, S. YAROVOI, D. B. CINES, W. FANG, E. ABRAHAM (2006): Involvement of the urokinase kringle domain in lipopolysaccharide-induced acute lung injury. J. Immunol. 177, 5550-5557. DOI: $10.4049 /$ jimmunol.177.8.5550

WARE, L. B., M. A. MATTHAY (2000): The acute respiratory distress syndrome. N. Engl. J. Med. 342, 1334-1349.

DOI: 10.1056/NEJM200005043421806
WU, D. D., P. H. PAN, B. LIU, X. L. SU, L. M. ZHANG, H. Y. TAN, Z. CAO, Z. R. ZHOU, H. T. LI, H. S. LI (2015): Inhibition of alveolar macrophage pyroptosis reduces lipopolysaccharide-induced acute lung injury in mice. Chin. Med. J. 128, 2638-2645.

DOI: $10.4103 / 0366-6999.166039$

ZALEWSKA-KASZUBSKA, J., D. GORSKA (2001): Antiinflammatory capabilities of macrolides. Pharmacol Res. 44, 451-454.

DOI: $10.1006 /$ phrs.2001.0884

ZHANG, X., C. Li, J. Li, Y. Xu, S. GUAN, M. ZHAO (2015): Protective effects of protocatechuic acid on acute lung injury induced by lipopolysaccharide in mice via p38MAPK and $\mathrm{NF}-\kappa \mathrm{B}$ signal pathways. Int. Immunopharmacol. 26, 229236.

DOI: 10.1016/j.intimp.2015.03.031

ZHANG, X., J. LI, C. CHEN, X. CI, Q. YU, X. ZHANG, X. DENG (2011): Protective effect of abamectin on acute lung injury induced by lipopolysaccharide in mice. Fundam. Clin. Pharmacol. 25, 700-707.

DOI: $10.1111 /$ j.1472-8206.2010.00896.X

ZHANG, Z., D. L. QIN, J. Y. WAN, Q. X. ZHOU, S. H. XIAO, K. WU (2008): Effects of asiaticoside on the balance of inflammatory factors of mouse's acute lung injury induced by LPS. Zhong Yao Cai. 31, 547-549.

ZHI, Q. M., L. T. YANG, H. C. SUN (2011): Protective effect of ambroxol against paraquat-induced pulmonary fibrosis in rats. Intern. Med. 50, 1879-1887.

DOI: 10.2169/internalmedicine.50.5407

Received: 5 July 2020

Accepted: 5 November 2020

\section{ER, A., B. DIK, D. COSKUN, H. ESER FAKI, E. BAHCIVAN: Utjecaj ambroksola na protuupalni učinak azitromicina u plućnom tkivu. Vet. arhiv 91, 665-671, 2021. \\ SAŽETAK}

Cilj ovog istraživanja bio je usporediti učinke dviju različitih doza ambroksola (AMB), primijenje-nih u kombinaciji s azitromicinom (AZIT), na koncentraciju citokina u bronhoalveolarnoj tekućini (BALF), odnosno na serumske biokemijske pokazatelje u slučaju akutne ozljede pluća izazvane lipopolisaharidom (LPS). Od ukupno 78 miševa, mužjaka Swiss albino soja, 6 je miševa stavljeno u kontrolnu skupinu ( 0 sati). Ostale životinje su podijeljene u tri jednake skupine: skupinu kojoj je dan LPS, skupinu kojoj je primijenjen LPS + AZIT + AMB30 i skupinu LPS + AZIT + AMB70. LPS, AZIT i AMB primijenjeni su intraperitonealno. BALF i uzorci seruma prikupljeni su prije aplikacije lijekova (0 sati) te 4, 8, 16 i 24 sata poslije aplikacije pod općom anestezijom, nakon čega su svi miševi eutanazirani cervikalnom dislokacijom. Određena je koncentracija tumorskog faktora nekroze alfa (TNF- $\alpha$ ), interleukina IL-6 i IL$10 \mathrm{u}$ BALF-u te koncentracija aspartat-aminotransferaze (AST), alkalne fosfataze (ALP), uree i kreatinina u serumu. Povećanje koncen-tracije TNF- $\alpha$ i IL-6 u skupini kojoj je dan LPS prevenirano je u razdoblju od 8 sati, odnosno 16 sati nakon aplikacije u skupini LPS + AZIT + AMB30. Osim toga, u obje je skupine preveniran porast koncentracije IL-6 nakon 16 sati. Kombinacija LPS + AZIT + AMB30 povećala je koncen-traciju IL-10 u periodu nakon 16 sati, a kombinacija LPS + AZIT + AMB70 nakon 4 sata. LPS je uzrokovao znakovit porast koncentracije uree u svim vremenima uzorkovanja i statističku fluktua-ciju drugih pokazatelja u različitim vremenima uzorkovanja. Povećana koncentracija ALP-a u skupini LPS smanjena je u pokusnim skupinama nakon 8 sati. Zaključeno je da kombinacija male do-ze AMB-a i AZIT-a može blagotvorno djelovati na plućne infekcije putem utjecaja na mrežu citokina.

Ključne riječi: akutna oštećenje pluća; ambroksol; azitromicin; BALF; citokin 
